Baseline

\title{
Metals contamination along the watershed and estuarine areas of southern Bohai Sea, China
}

\author{
$\mathrm{Li} \mathrm{Xu}^{\mathrm{a}, \mathrm{b}}$, Tieyu Wang ${ }^{\mathrm{a}, *}, \mathrm{Kun} \mathrm{Ni}^{\mathrm{a}, \mathrm{b}}$, Shijie Liu ${ }^{\mathrm{a}, \mathrm{b}}$, Pei Wang ${ }^{\mathrm{a}, \mathrm{b}}$, Shuangwei Xie ${ }^{\mathrm{a}, \mathrm{b}}$, Jing Meng ${ }^{\mathrm{a}, \mathrm{b}}$, \\ Xiaoqi Zheng ${ }^{\mathrm{a}, \mathrm{b}}$, Yonglong $\mathrm{Lu}^{\mathrm{a}, *}$ \\ a State Key Laboratory of Urban and Regional Ecology, Research Center for Eco-Environmental Sciences, Chinese Academy of Sciences, Beijing 100085, China \\ ${ }^{\mathrm{b}}$ Graduate University of Chinese Academy of Sciences, Beijing 100039, China
}

\section{A R T I C L E I N F O}

\section{Keywords:}

Metals

Watershed

Risk assessment

Land use

Gold mining

\begin{abstract}
A B S T R A C T
Distributions and magnitude of metals in water, sediment and soil collected from the watershed and estuarine areas of southern Bohai Sea, were investigated. The largest dissolved concentrations of As, $\mathrm{Cu}$ and $\mathrm{Zn}$ in water were $347.70,2755.00,2076.00 \mu \mathrm{g} / \mathrm{L}$, respectively, much higher than corresponding drinking water guidelines. The greatest concentrations of $\mathrm{Cu}, \mathrm{Zn}, \mathrm{Cr}, \mathrm{Ni}, \mathrm{Pb}, \mathrm{As}$ and $\mathrm{Cd}$ in sediments were $1462.2,1602.17,196.43,67.15,63.54,73.86$ and $1.41 \mathrm{mg} / \mathrm{kg}$, dw, respectively. The mean concentrations of $\mathrm{Cu}, \mathrm{Ni}, \mathrm{Cd}, \mathrm{Zn}, \mathrm{Cr}, \mathrm{Pb}$ and As in soils were 24.67, 24.73, 0.14, 64.75, 56.52, 25.12 and $9.34 \mathrm{mg} / \mathrm{kg}, \mathrm{dw}$, respectively. Land use was confirmed to be an important factor of influence on soil metal concentrations. Metal contents along the watershed of Jie River were significantly greater than in other locations. The detection of metals in relatively high concentrations from different environmental matrices in this region indicates the necessity of further studies.
\end{abstract}

(c) 2013 Elsevier Ltd. All rights reserved.
In the past few decades, metals contamination in the environment has been attracting increasing concern around the world due to their toxicity, persistence and bioaccumulation characteristics (Cheng, 2003; Davis and Atkins, 2001). Unlike organic pollutants which can be degraded to less harmful components by biological or chemical processes, metals are considered as not naturally decomposable. The environmental metal concentrations are influenced by both natural and anthropogenic factors including parent materials, industrial and domestic sewage discharges, mining, smelting, e-wastes recycling (Xu et al., 2011). China is currently the worlds' second largest economy as a result of rapid industrial development over the past few decades. However, this rapid economic growth has been accompanied by considerable environmental side effects, especially pollution by metals. Coastal and estuarine areas are among the most important places for human inhabitants, yet they are often the ultimate receptacles of pollutants (Pan and Wang, 2012). The distribution and contamination levels of metals in the watershed, estuaries, coastal, bay and sea environments in China have been extensively investigated (Gao and Chen, 2012; Ip et al., 2007; Zhang et al., 2009).

The Bohai Sea is a nearly enclosed interior sea located in northeast China and consists of Liaodong Bay, Bohai Bay, Laizhou Bay, and the middle sea (Meng et al., 2008). Due to intensive

\footnotetext{
* Corresponding authors. Tel.: +86 10 62849466; fax: +86 1062918177 (T.Y. Wang), tel.: +86 1062917903 (Y.L. Lu).

E-mail addresses: wangty@rcees.ac.cn (T. Wang), yllu@rcees.ac.cn (Y. Lu).
}

urbanization and industrialization, Bohai Sea and nearby coastal areas and estuaries have severe metal pollution problems (Wang et al., 2011b). Particularly, its proximity to Beijing, the capital of China, makes it one of the busiest seaways in the world ( $\mathrm{Hu}$ et al., 2010). Large amounts of metals are carried into this sea through either direct discharges or loads from rivers, such as the Yellow River, Liaohe River and Xiaoqing River. For example, the Liaohe River discharged $390 \mathrm{t}$ of metals into the sea in 2002, and the Yellow River totally discharged $200 \mathrm{t}$ of metals in 2003 (Wang and Wang, 2007). The accumulation of pollutants can be greater in enclosed and semi-enclosed areas where the exchange of water with the open seas is limited (Karageorgis et al., 2002). The watershed and estuarine environment has experienced dramatic reductions in species diversity and abundance, diseases in marine-cultured species, and habitat loss, which will ultimately destroy marine ecosystem structures and functions, and affect the health of human beings profoundly.

Metals contamination of Bohai Sea have been investigated over the past few years (Feng et al., 2011; Meng et al., 2008; Wang and Wang, 2007; Zhan et al., 2010), however, almost all previous studies have focused on downstream areas (coastal and estuarine systems, namely marine and saline water systems), such as the estuaries, the coasts and the bays along the Bohai Sea. The spatial distribution of arsenic (As) and metals as well as the corresponding environmental risks within the coastal watersheds in upstream areas (surface water systems, namely freshwater systems), especially in southern Bohai Sea, have received less attention. 
Furthermore, differences in arsenic and metal content in water, sediments and soils between upstream and downstream areas within the coastal watersheds are largely unknown at the regional scale. Therefore, Supplementary data on environmental quality in different environmental media of the entire region is urgently needed for a more comprehensive understanding. The objectives of this paper are: (a) to examine the spatial concentration distributions of As and metals in water, sediments and soils collected from the watersheds along the southern Bohai Sea, China, (b) to determine the contents of $\mathrm{As}, \mathrm{Cd}, \mathrm{Cr}, \mathrm{Cu}, \mathrm{Ni}, \mathrm{Pb}$ and $\mathrm{Zn}$ in soils under different land use, and (c) to investigate environmental risks associated with metal contents in different environmental media.

This study focuses on the watershed and estuarine areas of southern Bohai Sea, including the following nine cities: Cangzhou (CZ), Binzhou (BZ), Dezhou (DZ), Dongying (DY), Zibo (ZB), Weifang $(\mathrm{WF})$, Qingdao (QD), Yantai (YT) and Weihai (WH). Samples are numbered as follows: CZ1-3 in Cangzhou, BZ1-6 in Binzhou, DZ1 in Dezhou, DY1-6 in Dongying, ZB1 in Zibo, WF1-8 in Weifang, QD1-2 in Qingdao, YT1-12 in Yantai and WH1 in Weihai. In total, 40 water, 40 sediment and 37 soils samples were collected from 14 main rivers along southern Bohai Sea during September 2011 (Fig. 1). Throughout the survey, a global positioning system (GPS) was used to map the position of each sampling site.

Surface water samples were collected manually from the river. The samples were immediately filtered through acid-treated Millipore filters $(0.45 \mu \mathrm{m}$ mesh $)$ into pre-cleaned high density polyethylene (HDPE) containers in the field. The filtered samples were acidified to $\mathrm{pH}<2$ with ultra-purified $6 \mathrm{M} \mathrm{HNO}_{3}$ and then stored at $4{ }^{\circ} \mathrm{C}$ until analysis in the laboratory.

At each sampling point, approximately the top $5 \mathrm{~cm}$ of sediment was collected. All samples were sealed in clean polyethylene bags and put in a cooled box on site. Cooled samples were brought back to the lab and freeze-dried. And then, the sediment samples were crushed in an agate mortar, passed through a nylon 100-mesh sieve, and then stored at $4{ }^{\circ} \mathrm{C}$ in the dark before analysis of properties and concentrations of arsenic and metals.

Each soil sample was made from a mixture of five sub-samples collected from the center and at the four corners of an area of about $100 \times 100 \mathrm{~m}^{2}$. All soil sub-samples were collected at a depth of $0-$ $20 \mathrm{~cm}$ using a stainless steel shovel. Therefore, the 37 soil samples were composed from a total of 185 soil sub-samples collected. Grass and other sundries were removed from the surface of each sample location before the sample was collected. Soil was airdried, crushed in an agate mortar, passed through a nylon 100mesh sieve, and then stored at $4{ }^{\circ} \mathrm{C}$ in the dark before analysis of properties and concentrations of arsenic and metals.

Total concentrations of $\mathrm{Cu}, \mathrm{Zn}, \mathrm{Cd}, \mathrm{Cr}, \mathrm{Ni}$, As and $\mathrm{Pb}$ in the water were analyzed using Inductively Coupled Plasma- Mass Spectrometry (ICP-MS) with an analytical precision better than $10 \%$. Sediments and soil were digested with a mixture of concentrated $\mathrm{HCl}-\mathrm{HNO}_{3}-\mathrm{HF}-\mathrm{HClO}_{4}$ (NEB, 1998). Concentrations of metals, i.e., $\mathrm{Cd}, \mathrm{Cu}, \mathrm{Ni}, \mathrm{Pb}, \mathrm{Cr}$ and $\mathrm{Zn}$ in the digestion solution were determined using ICP-MS. The digestion for arsenic (As) determination was done using aqua regia $\left(\mathrm{HCl}: \mathrm{HNO}_{3}=3: 1\right)$ as recommended by the State Environmental Protection Administration of China (GB/T 22105-2008) (CSBTS, 2008). Standard reference materials, GBW-7 sediment and GSS- 8 soil, obtained from the Center of National Standard Reference material of China were analyzed as part of the quality assurance and quality control (QA/QC) procedures. The metal analytical concentrations for GBW-7 and GSS-8 were within the range of the certified value and the replicate analysis of each batch of samples showed that the analytical precision was within $10 \%$ variability. Samples were carefully handled to avoid introduction or loss of trace elements during preparation and analysis. All materials used during analytical determinations were kept in Teflon or other metal-free containers.
Statistical analysis was conducted using Microsoft Excel and SPSS 13.0 statistical software on a personal computer. ESRI ArcGIS 10.0 for Windows was used for the area digitization in order to display the spatial distribution of arsenic and metal concentrations in water, sediments and soil and corresponding risk indices.

Dissolved trace metals and arsenic in water at 40 different sites along the watershed and estuarine areas of southern Bohai Sea were summarized in Table 1 . In order to precisely reveal their spatial distribution, the contents of arsenic and metals at every sampling site are also displayed in Fig. 2. The greatest concentrations of $\mathrm{Cu}, \mathrm{Ni}, \mathrm{Pb}$ and As occurred at location YT5, while the greatest concentrations of $\mathrm{Zn}$ and $\mathrm{Cd}$ were found at site YT6, both from the Jie River. The Jie River is located in the border of Zhaoyuan County, which is known as 'Gold County' in China. The gold reserves of Zhaoyuan County were abundant, and it has a long history of gold mining. The gold-bearing ores and gravels usually contain many toxic elements such as arsenic, copper, zinc, lead, and mercury. A significant increase in environmental toxic metal concentrations can happen during gold mining (Edinger et al., 2008). Meanwhile, the smelting processes of ores and subsequent leaching of tailings also cause pollution with metals and arsenic. In addition, higher $\mathrm{Cd}$ and $\mathrm{Ni}$ concentration might be ascribed to the effluents of a variety of industrial plants scattered along the river bank (leather factory, flour mill, oil refining plants). The maximum $\mathrm{Cr}$ concentration was found in YT10 from the Jia River. As a water-receiving body, the Jia River may be influenced by both industrial and domestic wastewater from the Yantai city.

To better understand the extent of arsenic and metal pollution in water along the watershed and estuarine areas of southern Bohai Sea, we compared the results of our analysis with those in drinking water guidelines and in other studies. Comparisons with drinking water guidelines established by WHO, China and US EPA showed that, the mean concentration of As was higher than the guideline values. The maximum concentrations of $\mathrm{Cr}$ and $\mathrm{Pb}$ are lower than the guideline values, while the maximal Ni concentration was much higher than that of Chinese guidelines but lower than WHO guidelines. The mean concentrations of $\mathrm{Cu}, \mathrm{Zn}$ and $\mathrm{Cd}$ are much lower than the critical values, while their peak contents are higher than the critical values for drinking water quality. In addition, mean contents of $\mathrm{Pb}, \mathrm{Cr}, \mathrm{Ni}, \mathrm{Cu}$ and $\mathrm{Cd}$ in water along the watershed and estuarine areas of southern Bohai Sea were much higher than world average background values. In general, the concentrations of $\mathrm{Cr}, \mathrm{Ni}, \mathrm{Cd}$ and $\mathrm{Pb}$ in water in the study areas were comparable to or lower than those observed in other regions. The concentrations of $\mathrm{Cr}, \mathrm{Ni}, \mathrm{Cd}$ and $\mathrm{Pb}$ in water, however, were comparable to or higher than those observed in other regions.

Sediments play a major role in identifying the pollution pattern of aquatic systems. They act as both carriers and sinks for contaminants and therefore reflect the history of pollution and provide a record of catchment inputs into aquatic ecosystems (Pan and Wang, 2012; Pekey, 2006). The concentrations of metals and arsenic in surface sediments collected along the watershed and estuarine areas of southern Bohai Sea were presented in Table 2. In order to precisely present their spatial distribution, the arsenic and metals contents of every sampling site are shown in Fig. 3. The greatest concentrations of $\mathrm{Cu}, \mathrm{Zn}, \mathrm{Cr}, \mathrm{Ni}, \mathrm{Pb}, \mathrm{As}$ and $\mathrm{Cd}$ were 1462.2, 1602.17, 196.43, 67.15, 63.54, 73.86 and $1.41 \mathrm{mg} / \mathrm{kg}$, respectively. The greatest concentrations of $\mathrm{Cu}, \mathrm{Zn}, \mathrm{Cd}$ and $\mathrm{Pb}$ and the second largest contents of As occurred in site YT6, while the greatest As concentrations as well as the second largest contents of $\mathrm{Cu}, \mathrm{Cd}$ and $\mathrm{Pb}$ were found in site YT5. The mining and smelting of gold ore was presumably responsible for the high concentration of $\mathrm{Cu}, \mathrm{Zn}, \mathrm{Cd}, \mathrm{Pb}$ and $\mathrm{As}$ in sediments. Relatively high metal and arsenic concentrations have more often been reported in areas with gold mining around the world (Melo and Fletcher, 1999; Tarras-Wahlberg et al., 2001; van Straaten, 2000). At site 


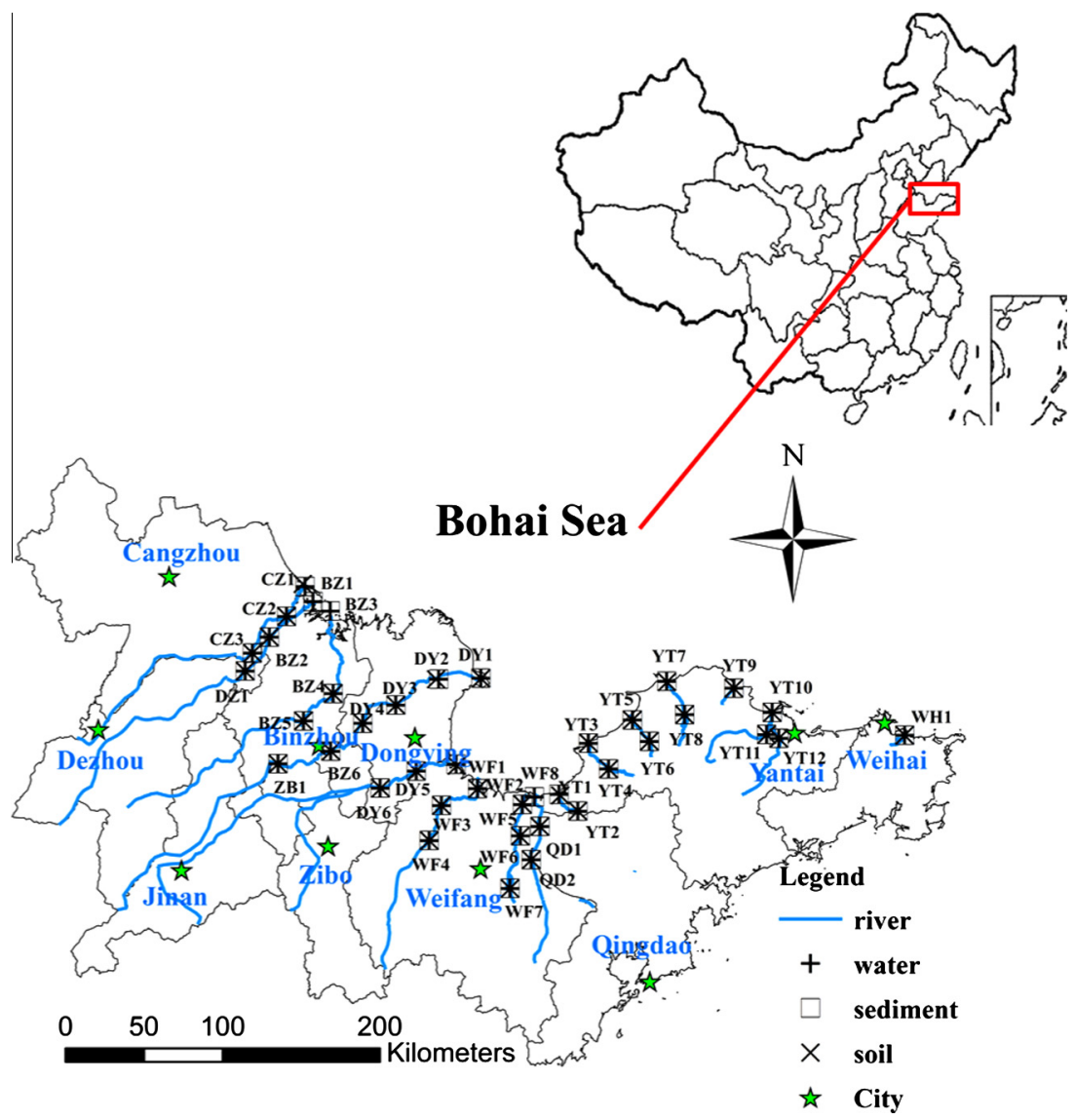

Fig. 1. Sampling sites along the watershed and estuarine areas of southern Bohai Sea.

Table 1

Concentrations of dissolved arsenic and metals in water along the watershed and estuarine areas of southern Bohai Sea (ug/L).

\begin{tabular}{|c|c|c|c|c|c|c|c|c|c|c|c|c|}
\hline \multirow[t]{3}{*}{ Metals } & \multirow[t]{3}{*}{ Mean } & \multirow[t]{3}{*}{ Min } & \multirow[t]{3}{*}{ Max } & \multicolumn{4}{|c|}{ Drinking water guidelines } & \multirow[t]{3}{*}{ Background World Average $^{\mathrm{d}}$} & \multirow[t]{3}{*}{ Yangtze River $^{\mathrm{e}}$} & \multirow[t]{3}{*}{ Han River ${ }^{\mathrm{f}}$} & \multirow[t]{3}{*}{ Rhine River $^{\mathrm{g}}$} & \multirow[t]{3}{*}{ Nakkavagu $^{\mathrm{h}}$} \\
\hline & & & & \multirow[t]{2}{*}{$\mathrm{WHO}^{\mathrm{a}}$} & \multirow[t]{2}{*}{ China $^{\mathrm{b}}$} & \multicolumn{2}{|c|}{ US EPA } & & & & & \\
\hline & & & & & & MCLG & MCL & & & & & \\
\hline $\mathrm{Cr}$ & 4.35 & 0.66 & 31.0 & 50 & 50 & 100 & 100 & nd & 8.90 & 8.14 & nd & 16.8 \\
\hline $\mathrm{Ni}$ & 7.09 & 1.32 & 58.9 & 70 & 20 & nd & nd & 0.3 & 3.69 & 1.71 & 2.00 & 26.7 \\
\hline $\mathrm{Cu}$ & 77.5 & 0.38 & 2755.0 & 2000 & 1000 & 1300 & 1300 & 1.00 & 8.40 & 13.4 & 3.40 & nd \\
\hline $\mathrm{Zn}$ & 75.5 & 0.11 & 2076.0 & nd & 1000 & nd & nd & 10 & 18.8 & nd & 33.0 & 98.6 \\
\hline As & 18.6 & 1.50 & 347.7 & 10 & 10 & 0 & 10 & nd & 7.04 & 14.2 & nd & 29.2 \\
\hline $\mathrm{Cd}$ & 0.38 & 0.08 & 6.26 & 3 & 5 & 5 & 5 & 0.02 & 0.28 & 2.31 & 5.30 & nd \\
\hline $\mathrm{Pb}$ & 1.41 & 0.94 & 3.28 & 10 & 10 & 0 & 15 & 0.2 & 6.40 & 9.26 & 5.70 & 2.10 \\
\hline
\end{tabular}

Maximum Contaminant Level Goal (MCLG); Maximum Contaminant Level (MCL) and nd - not detected.

a WHO (2006) Drinking water guidelines.

b Chinese (2007) Drinking water guidelines.

c USEPA (2006) Drinking water Standards.

d Klavins et al. (2000).

e Wang et al. (2011a).

f Li and Zhang (2010b).

g Klavins et al. (2000).

h Krishna et al. (2009).

YT5, some of the greatest metal and arsenic concentrations were observed in water. The greatest $\mathrm{Cr}$ concentration was found at site DY6 from the Xiaoqing River. The Xiaoqing River was once a heavily polluted river that received industrial effluent and domestic sewage from the cities of Jinan, Zibo, Dongying and Weifang. The watershed encompasses a great deal of densely industrialized zones with paper making, electronics, printing and dyeing, and petroleum and chemical industries (Sun, 2009). Peak concentrations of Ni were observed at site WF7 from the Wei River. Elevated levels of $\mathrm{Ni}$ in rivers have been associated with effluents (Wang et al., 2011a), so this Ni pollution may have originated from wastewater from nearby plants.

The metals and arsenic concentrations in the sediments were compared to marine sediment criteria and standards (GB 186682002) enacted by the China State Bureau of Quality and Technical Supervision (CSBTS) (Table 2). According to this standard, the first class quality is suitable for mariculture, nature reserve, endangered species reserve, and leisure activities such as swimming; the 

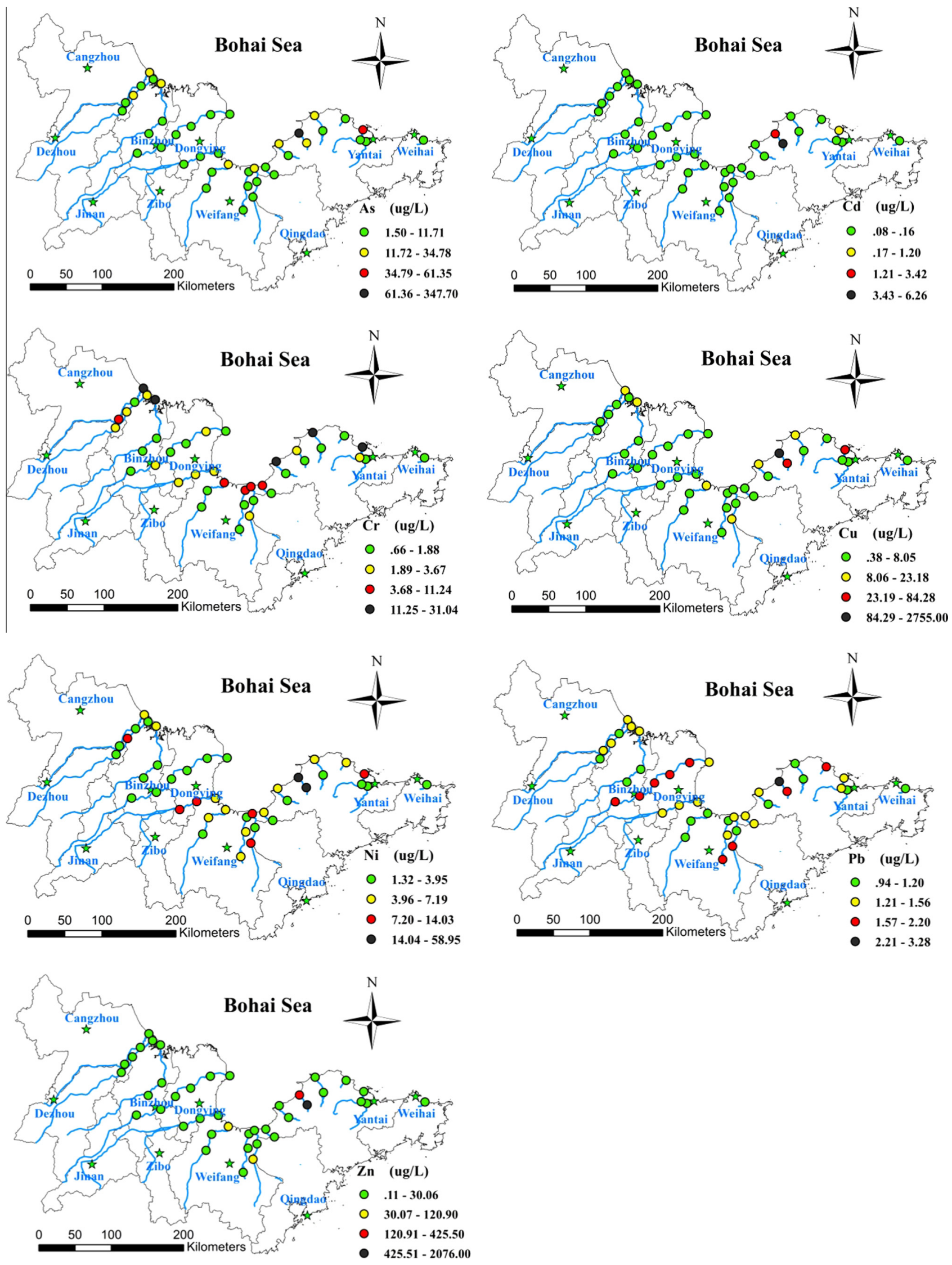

Fig. 2. Spatial variance of $\mathrm{Cr}, \mathrm{Ni}, \mathrm{Cu}, \mathrm{Zn}, \mathrm{As}, \mathrm{Cd}$ and $\mathrm{Pb}$ concentrations in the water along the watershed and estuarine areas of southern Bohai Sea. 
Table 2

Concentrations of arsenic and metals in sediment along the watershed and estuarine areas of southern Bohai Sea (mg/kg).

\begin{tabular}{|c|c|c|c|c|c|c|c|c|c|c|c|c|c|}
\hline \multirow[t]{2}{*}{ Metals } & \multirow[t]{2}{*}{ Mean } & \multirow[t]{2}{*}{ Min } & \multirow[t]{2}{*}{ Max } & \multicolumn{3}{|c|}{ CSBTS $^{a}$} & \multirow{2}{*}{$\begin{array}{l}\text { NorthernBohai } \\
\text { Bay }^{\mathrm{b}}\end{array}$} & \multirow{2}{*}{$\begin{array}{l}\text { Peral River } \\
\text { estuary }^{c}\end{array}$} & \multirow{2}{*}{$\begin{array}{l}\text { Western } \\
\text { Bohai Bay }^{\mathrm{d}}\end{array}$} & \multirow{2}{*}{$\begin{array}{l}\text { Izmit Bay, } \\
\text { Turkey }^{\mathrm{e}}\end{array}$} & \multirow{2}{*}{$\begin{array}{l}\text { Masan } \\
\text { Bay, } \\
\text { Korea }^{\text {f }}\end{array}$} & \multirow{2}{*}{$\begin{array}{l}\text { Tokyo } \\
\text { Bay, } \\
\text { Japang }\end{array}$} & \multirow{2}{*}{$\begin{array}{l}\text { Bremen } \\
\text { Harbor, } \\
\text { Germany }\end{array}$} \\
\hline & & & & $\begin{array}{l}\text { Class } \\
\text { I }\end{array}$ & $\begin{array}{l}\text { Class } \\
\text { II }\end{array}$ & $\begin{array}{l}\text { Class } \\
\text { III }\end{array}$ & & & & & & & \\
\hline $\mathrm{Cr}$ & 54.3 & 0.45 & 196.4 & 80 & 150 & 270 & 47.0 & 118.1 & 53.1 & 74.3 & 67.1 & 71.1 & 131.0 \\
\hline $\mathrm{Ni}$ & 23.4 & 0.06 & 1.41 & nd & nd & nd & nd & nd & 31.4 & nd & 28.8 & 30.5 & 60.0 \\
\hline $\mathrm{Cu}$ & 65.9 & 0.22 & 1462.4 & 35 & 100 & 200 & 13.0 & 81.0 & 27.9 & 67.6 & 43.4 & 49.7 & 87.0 \\
\hline $\mathrm{Zn}$ & 122.7 & 8.10 & 196.4 & 150 & 350 & 600 & 60.0 & 140.0 & 83.6 & 930.0 & 206.3 & 275.7 & 790.0 \\
\hline As & 9.63 & 0.27 & 73.9 & 20 & 65 & 93 & 8.50 & 33.1 & nd & 21.8 & nd & nd & 15.0 \\
\hline $\mathrm{Cd}$ & 0.18 & 0.06 & 1.41 & 0.5 & 1.5 & 5 & 0.15 & 5.6 & 0.13 & 4.90 & 1.24 & 1.00 & 6.00 \\
\hline $\mathrm{Pb}$ & 24.5 & 16.8 & 63.5 & 60 & 130 & 250 & 25.0 & 105.9 & 20.5 & 102.0 & 43.9 & 47.0 & 122.0 \\
\hline
\end{tabular}

a CSBTS (China State Bureau of Quality and Technical Supervision).2002. National Standards GB 18668-2002-Marine Sediment Quality, The People's Republic of China (in Chinese); and nd-not detected.

b Luo et al. (2010).

c Pan and Wang (2012).

d Feng et al. (2011).

e Pekey (2006).

f Hyun et al. (2007).

g Fukushima et al. (1992).

h Hamer and Karius (2002).

second class quality can be used for industry and tourism site; and the third class can just be used for harbor (Gao and Chen, 2012). There are no Ni standards available in GB 18668-2002. The contents of all metals and arsenic were below the threshold values for Class III sediments at all the sites, except for $\mathrm{Cu}$ at the sites YT5 and YT6 as well as $\mathrm{Zn}$ at the site YT5. The $\mathrm{Cu}, \mathrm{Zn}, \mathrm{Cr}, \mathrm{Pb}$, As and $\mathrm{Cd}$ contents at $75 \%, 87.5 \%, 80 \%, 97.5 \%, 95 \%$ and $95 \%$ sampling sites, respectively, were within the range for Class I sediment. The $\mathrm{Cu}, \mathrm{Zn}, \mathrm{Cr}, \mathrm{Pb}$, As and Cd contents at 7, 2, 7, 1, 1 and 2 sampling sites were above Class I while below Class II threshold values, respectively. The number of sampling sites at which the $\mathrm{Cu}, \mathrm{Zn}$, $\mathrm{Cr}, \mathrm{Pb}$, As and $\mathrm{Cd}$ contents were above Class II while below Class III threshold values were $1,2,1,0,1$ and 0 , respectively. $65 \%$ of sampling sites was clean enough to be classified as Class I grade in terms of contents of all the five metals. Metal concentrations in southern Bohai Sea were comparable to or lower than those observed in other regions in China or around the world (Table 2). Moreover, we found the metal concentrations in southern Bohai Sea were lower than those previously reported at other large industrialized/urban ports and estuaries such as Izmit Bay (Turkey), Peral River estuary (China), Masan Bay (Korea), Tokyo Bay (Japan) and Bremen Harbor (Germany). In general, except at several extremely contaminated sites, the metal contaminations along the coasts and estuaries of southern Bohai Sea were no worse than those observed in other regions around the world.

To better understand the arsenic and metal pollution in sediment and water between upstream and downstream areas, we compared the results of our analysis with those in downstream areas along Bohai Sea. The mean concentrations of $\mathrm{Cu}, \mathrm{Cr}$ and $\mathrm{Ni}$ in sediment of upstream were higher than those observed in the downstream areas. The mean concentrations of $\mathrm{Pb}$ and $\mathrm{Ni}$ in sediment of upstream were higher than those observed in most of the downstream areas. The mean concentrations of $\mathrm{Cd}$ and As in sediment of upstream were higher than those observed in half of the downstream areas. In general, metal pollution in sediment of upstream was more serious than that of downstream areas. If only the results of this study were taken into consideration, we could conclude that the arsenic and metal pollution in water of upstream was less serious than that of downstream areas. However, when compared with other research results, we could find that the arsenic and metal pollution in water of upstream was more serious than that of downstream areas. The most important reason for this phenomenon is the variations of metals concentration in water are much bigger than that in sediments at different time. In addition, the study area, sampling method and analytical method differ somewhat Table 3.

Soils are the critical interface environment where rock, air and water interact (Luo et al., 2007b). Soil can be polluted by irrigation with wastewater, which may then, through run-off from soil, be a source of metals to aquatic ecosystems (Xu et al., 2011). The assessment of soil metal contamination along the watershed and estuarine areas of southern Bohai Sea, and furthermore the protection of soil from metal contamination, are therefore very important for safeguarding water quality in nearby rivers and the Bohai Sea. The concentrations of metals in soils and different land uses along the watershed and estuarine areas of southern Bohai Sea $(\mathrm{mg} / \mathrm{kg})$ are shown in Table 4. Because most study sites were located in Shandong Province, the metal and arsenic concentrations measured in this study were compared with the corresponding background values in Shandong Province as reported in the literature. The mean concentration of $\mathrm{Cd}(0.14 \mathrm{mg} / \mathrm{kg}, \mathrm{dw})$ was greater than its background value $(0.08 \mathrm{mg} / \mathrm{kg}, \mathrm{dw})$, and $95 \%$ soil samples exceeded the reference value for $\mathrm{Cd}$. It can thus be concluded that surface soils along the watershed and estuarine areas of southern Bohai Sea were contaminated with $\mathrm{Cd}$. Cd is relatively mobile in soils (Babic et al., 1998), and thus, could migrate to the nearby rivers and Bohai Sea and degrade the quality of water.

The mean concentration of $\mathrm{Cu}$ in soils was $24.67 \mathrm{mg} / \mathrm{kg}$, dw. The $\mathrm{Cu}$ had a coefficient of variation of $88.77 \%$ which is the largest of the elements we studied. This is likely due to the heterogeneity of $\mathrm{Cu}$ distribution, with a few locations having greater concentrations. The mean concentrations of $\mathrm{Ni}, \mathrm{Cr}, \mathrm{Zn}, \mathrm{Pb}$ and As were 24.73, 56.52, 64.75, 25.12 and $9.34 \mathrm{mg} / \mathrm{kg}$, dw, respectively. The numbers of samples exceeding the corresponding reference values for $\mathrm{Ni}, \mathrm{Cr}, \mathrm{Zn}, \mathrm{Pb}$ and As were 21, 12, 14, 19 and 18 respectively. Thus, $\mathrm{Ni}, \mathrm{Cr}, \mathrm{Zn}, \mathrm{Pb}$ and As contaminations in soils along the watershed and estuarine areas of southern Bohai Sea deserves more attention.

Land use is an important factor affecting metal distributions, for different land uses can result in differences in metal sources, farming practices, and soil properties (Kim et al., 2003). The figure about the land use along the watershed of southern Bohai Sea was listed in Appendix I. Four types of land uses (fallow, woodland, arable land and orchard) were identified along the watershed and estuarine areas of southern Bohai Sea. The largest average values for $\mathrm{Cu}(36.63 \mathrm{mg} / \mathrm{kg}, \mathrm{dw})$ and $\mathrm{Zn}(72.17 \mathrm{mg} / \mathrm{kg}, \mathrm{dw})$ were found 

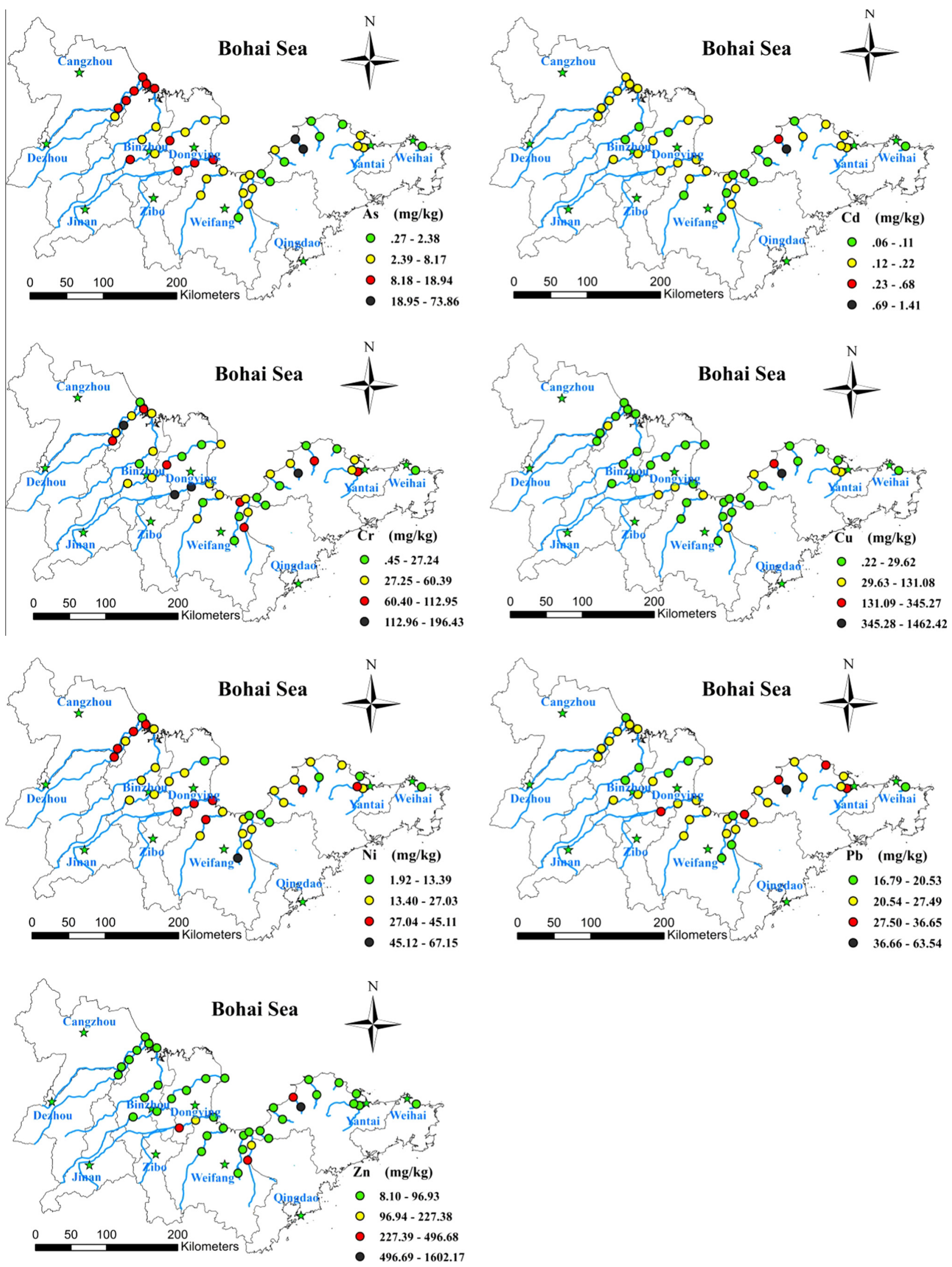

Fig. 3. Spatial variance of $\mathrm{Cr}, \mathrm{Ni}, \mathrm{Cu}, \mathrm{Zn}, \mathrm{As}, \mathrm{Cd}$ and $\mathrm{Pb}$ concentrations in the sediment along the watershed and estuarine areas of southern Bohai Sea. 
in the orchard. Holland and Solomona (1999) proposed that elevated soil copper concentrations in orchard soils can be the results of long-term use of copper-based fungicides. Relatively high copper content has been reported in orchard soils around the world (Besnard et al., 2001; Deluisa et al., 1996; Luo et al., 2007a). Similarly, higher Zn concentration in orchards could result from longterm application of phosphate fertilizers and sludge containing Zn (Nan et al., 2002). Phosphate deposits are known to have high concentrations of $\mathrm{Zn}$.

The largest average values for $\mathrm{Ni}(26.60 \mathrm{mg} / \mathrm{kg}, \mathrm{dw}), \mathrm{Cd}$ $(0.15 \mathrm{mg} / \mathrm{kg}, \mathrm{dw})$ and $\mathrm{Cr}(60.92 \mathrm{mg} / \mathrm{kg}, \mathrm{dw})$ were found in the arable land. In addition, maximal values of $\mathrm{Ni}(43.99 \mathrm{mg} / \mathrm{kg}, \mathrm{dw}), \mathrm{Cd}$ $(0.24 \mathrm{mg} / \mathrm{kg}, \mathrm{dw})$ and $\mathrm{Cr}(101.26 \mathrm{mg} / \mathrm{kg}, \mathrm{dw})$ were also found in arable land. The yield of arable land can be enhanced by irrigating with wastewater and applying sewage sludge due to their high nutrient contents, primarily $\mathrm{N}$ and $\mathrm{P}$ (Ramirez-Fuentes et al., 2002). However, many types of metals in wastewater or sewage sludge may accumulate in soil, especially $\mathrm{Ni}, \mathrm{Cd}$ and $\mathrm{Cr}$ (Andres and Francisco, 2008; Mapanda et al., 2005). There is a long history of wastewater irrigation and sludge application in Shandong Province (Zhang et al., 2008). Therefore, it is very probable that the remarkably high contents of $\mathrm{Ni}, \mathrm{Cd}$ and $\mathrm{Cr}$ in arable land were a consequence of wastewater irrigation and land application of sludge.

The largest average $\mathrm{Pb}(28.59 \mathrm{mg} / \mathrm{kg}, \mathrm{dw})$ and $\mathrm{As}(10.47 \mathrm{mg} / \mathrm{kg}$, $\mathrm{dw}$ ) contents were found in woodland, and meanwhile, the greatest contents of $\mathrm{Pb}(51.36 \mathrm{mg} / \mathrm{kg}$, dw) and $\mathrm{As}(25.28 \mathrm{mg} / \mathrm{kg}$, dw $)$, as well as the largest $\mathrm{Cu}(125.52 \mathrm{mg} / \mathrm{kg}$, dw) and $\mathrm{Zn}(154.34 \mathrm{mg} / \mathrm{kg}$, $\mathrm{dw}$ ) contents, were also in woodland. Moreover, the greatest concentrations of $\mathrm{Pb}, \mathrm{As}, \mathrm{Cu}$ and $\mathrm{Zn}$ were observed in the same location (YT5). Significant metal contamination at YT5 can be ascribed to atmospheric pollutants. The rate of atmospheric deposition depends on the proximity to point sources of pollution, such as heavy industry (Nicholson et al., 2003). There were relatively intensive gold mining activities next to the YT5 sampling site. At this location, some of the greatest arsenic and metals concentrations were also observed in water and sediment. It is therefore likely that the mining and smelting of gold ore is primarily responsible for the high concentrations of $\mathrm{Cu}, \mathrm{Zn}, \mathrm{Pb}$ and $\mathrm{As}$ in woodland and soils.

The lowest mean values for $\mathrm{Cu}(15.50 \mathrm{mg} / \mathrm{kg}, \mathrm{dw}), \mathrm{Zn}$ (45.15 mg/kg, dw), Cd (0.12 mg/kg, dw), Pb (22.29 mg/kg, dw), Cr $(45.51 \mathrm{mg} / \mathrm{kg}, \mathrm{dw})$ and $\mathrm{Ni}(19.59 \mathrm{mg} / \mathrm{kg}, \mathrm{dw})$ were found in fallow soils. The fallow soils contained less metal, for it had received less fertilizers and insecticides than arable land and orchard soils. In addition, the lower metal concentrations detected in fallow soils might be due to drift of metals and atmospheric deposition from nearby areas (de Vries et al., 2003). However, the smallest mean As content $(6.83 \mathrm{mg} / \mathrm{kg}$, dw) was found in orchard. It has been proposed by some experts that the arsenic concentrations in orchard soils were high, very probably due to the long-term use of arsenic-based fungicides (Gaw et al., 2003; Merry et al., 1983). We did not find high arsenic concentrations in the orchard soils along the watershed and estuarine areas of southern Bohai Sea, this may be ascribed to the use of other kinds of insecticides, based on $\mathrm{Cu}, \mathrm{Zn}$ or lead rather than arsenic-based fungicides.

To quantitatively evaluate the relationships among arsenic and metals in sediments, water and soil, PC analysis was applied. The PCA results of metals in sediment, water and soil were listed in Appendix II. Take sediment for example, the components were ranked by seven values. The cumulative percentages of the variations explained by the first two components, two factors originate with a cumulative variance of $82.03 \%$ for the sediment samples. The $66.28 \%$ of total variance is contributed by PC 1 , showing higher loadings for $\mathrm{Cu}, \mathrm{Zn}, \mathrm{Cd}, \mathrm{Pb}$ and As, the catchment of southern Bohai Sea has a high density of population and industrial enterprises (such as smelting plants, thermal power plants, galvanization factories, paper mills, leather industry, electronic equipment factories) that discharge great amounts of wastewater and solid wastes. So, discharge from industrial enterprises was likely responsible for the introduction of metals and arsenic. Secondly, the mining and smelting of ores might be another important source of metals and arsenic. In addition, some metals can have lithogenic source, as it forms a number of soluble salts or insoluble salts according to the prevailing pedogenic processes (Pan and Wang, 2012). Therefore, this component may be attributable to a mixed source both from geogenic origins and from anthropogenic inputs. PC2 could be considered as a natural component, because the variability of the heavy metals seems to be controlled by parent rocks, moreover, the degree of contamination of $\mathrm{Cr}$ and $\mathrm{Ni}$ were lower than the other elements. This result suggests the distribution of $\mathrm{Cr}$ and $\mathrm{Ni}$ had a lithogenic origin, and these two heavy metals were included in the second principal component. Based on the PCA method, we can also get the possible sources for arsenic and metals in water and soil. For water, $\mathrm{Cu}, \mathrm{Zn}, \mathrm{Cd}, \mathrm{Pb}, \mathrm{Ni}$ and $\mathrm{As}$ could be identified as combination of factors associated with natural and anthropogenic sources, $\mathrm{Cr}$ could be considered to be dominated by "natural factor". For soil, both the natural and anthropogenic sources have contributed to the observed concentrations of $\mathrm{Cu}$, $\mathrm{Zn}, \mathrm{Cd}, \mathrm{Pb}, \mathrm{Ni}$ and $\mathrm{As}$, and $\mathrm{Cr}$ may originate from the natural parent materials of the soils.

Human exposure to the target pollutants is through three main pathways: (a) direct ingestion, (b) inhalation through the mouth and nose, and (c) dermal absorption. Ingestion and dermal absorption are the main routes of exposure in surface water environments (Wu et al., 2009). Considering these two pathways, Hazard Quotients (HQs) associated with corresponding metals were assessed with a risk assessment model. The calculation formulas and related parameters were listed in Appendix III.

The HQs of metals and arsenic for local residents through ingestion and dermal routes were calculated. If the HQ exceeds 1 , it suggests that the water could possibly have deleterious effects on the residents' health (Wu et al., 2009). In the study area, all HQ $\mathrm{dermal}_{\mathrm{d}}$ values were less than 1 , indicating that the dermal adsorption of metals and arsenic will have little or no health effects. Furthermore, the $\mathrm{HQ}_{\text {ingestion }}$ values of most elements were less than 1 , suggesting that these elements pose little or no risk to local residents (Karim, 2011). However, the $\mathrm{HQ}_{\text {ingestion }}$ values of As from 11 sites was bigger than 1, suggesting that As could have deleterious health effects for residents at these sites. The results demonstrated that arsenic was the most important pollutant in water along the watershed and estuarine areas of southern Bohai Sea. Arsenic has been proven to potentially cause diseases in people and animals, including hypertension, diabetes, disorders of nervous system and the cancers of lung, liver, bladder and skin ( $\mathrm{Li}$ and Zhang, 2010a). The spatial distribution of $\mathrm{HQ}_{\text {ingestion }}$ of As was precisely presented in Fig. 4. The largest As HQ ingestion value i.e., 31.8, was found at the site YT5. In addition, the HQ ingestion of $\mathrm{Cu}$ at site YT5 was 1.89 , suggesting that $\mathrm{Cu}$ may have serious health concerns for residents in this area. To safeguard the health of local residents as well as the sustainable development of the local aqueous ecosystem, remediation (removal of arsenic and copper) is required as soon as possible.

We must note that the methods adopted in this study have some inherent uncertainties, as has been emphasized by the USEPA and other documents (Wei et al., 2006). First, the exposure parameters employed in this study were taken from the USEPA and WHO, which might not be specific to Chinese situations. Second, the true exposure conditions in the study area, including age variation, receptor, temporal variations of pollutant concentrations and daily water intake, could not accurately be quantified. Moreover, the effects of contaminants may be altered by physiochemical processes. Therefore, a more precise assessment for metals and arsenic should 
Table 3

The metal pollution between upstream and domestream along the watershed of southern Bohai Sea.

\begin{tabular}{|c|c|c|c|c|c|c|c|c|}
\hline Media & $\mathrm{Cu}$ & $\mathrm{Pb}$ & $\mathrm{Zn}$ & $\mathrm{Cr}$ & $\mathrm{Cd}$ & As & $\mathrm{Ni}$ & Reference \\
\hline \multicolumn{9}{|l|}{ Sediment } \\
\hline Upstream & 82.5 & 24.9 & 156.7 & 63.57 & 0.18 & 9.19 & 26.7 & This study \\
\hline Downstream area & 38.0 & 24.0 & 66.01 & 38.88 & 0.16 & 10.4 & 18.1 & This study \\
\hline Downstream area & 22.1 & 53.8 & 78.4 & 60.5 & 0.25 & 7.70 & nd & Zhang (2010) \\
\hline Downstream area & 10.5 & 7.70 & 334.3 & 38.7 & 0.98 & 10.5 & nd & Huang and Pang (1992) \\
\hline Downstream area & 18.6 & 13.3 & 32.0 & 20.0 & 0.13 & 9.00 & nd & Wu et al. (2007) \\
\hline Downstream area & 13.5 & 16.7 & 49.1 & 62.1 & 0.21 & 7.74 & nd & Liu et al. (2009) \\
\hline Downstream area & 13.3 & 20.2 & 59.4 & 57.1 & 0.08 & 13.1 & 19.4 & Hu et al. (2009) \\
\hline \multicolumn{9}{|l|}{ Water } \\
\hline Upstream & 6.53 & 1.39 & 96.6 & 1.79 & 0.36 & 7.05 & 5.93 & This study \\
\hline Downstream area & 195.7 & 1.44 & 40.7 & 8.61 & 0.42 & 37.9 & 9.05 & This study \\
\hline Downstream area & 2.65 & 0.51 & 37.67 & nd & 0.68 & 0.92 & nd & Tang (2011) \\
\hline Downstream area & 3.45 & 0.22 & 15.8 & nd & 0.03 & 3.76 & nd & Tang (2011) \\
\hline Downstream area & 2.01 & 0.30 & nd & 0.17 & 0.30 & 1.86 & nd & Zhang (2010) \\
\hline Downstream area & 2.54 & 7.18 & 26.9 & 0.40 & 0.12 & 1.26 & nd & Meng et al., (2008) \\
\hline
\end{tabular}

Table 4

Descriptive statistics of metal concentrations in the studied soils along the watershed and estuarine areas of southern Bohai Sea ( $\mathrm{mg} / \mathrm{kg}$, dw).

\begin{tabular}{|c|c|c|c|c|c|c|c|c|c|}
\hline Land use & $N$ & Parameter & $\mathrm{Cu}$ & $\mathrm{Ni}$ & $\mathrm{Cd}$ & $\mathrm{Zn}$ & $\mathrm{Cr}$ & $\mathrm{Pb}$ & As \\
\hline \multirow[t]{4}{*}{ Total } & 37 & Mean & 24.67 & 24.73 & 0.14 & 64.75 & 56.52 & 25.12 & 9.34 \\
\hline & & $\mathrm{CV} \%$ & 88.77 & 35.18 & 30.71 & 41.62 & 31.33 & 23.02 & 51.82 \\
\hline & & Background value $^{a}$ & 21.7 & 23.0 & 0.08 & 61.9 & 65.2 & 24.3 & 8.70 \\
\hline & & Number exceeding values & 15 & 21 & 35 & 14 & 12 & 19 & 18 \\
\hline \multirow[t]{4}{*}{ Fallow } & 5 & Mean & 15.50 & 19.59 & 0.12 & 45.15 & 45.51 & 22.29 & 8.18 \\
\hline & & SD & 12.57 & 12.95 & .054 & 30.17 & 20.87 & 3.90 & 4.04 \\
\hline & & Minimum & 2.85 & 2.68 & 0.05 & 6.41 & 18.75 & 17.38 & 3.37 \\
\hline & & Maximum & 35.59 & 36.85 & 0.20 & 91.15 & 71.81 & 26.31 & 12.68 \\
\hline \multirow[t]{4}{*}{ Woodland } & 8 & Mean & 34.73 & 22.49 & 0.13 & 70.91 & 50.98 & 28.59 & 10.47 \\
\hline & & SD & 40.75 & 7.35 & .037 & 37.69 & 14.81 & 10.20 & 7.15 \\
\hline & & Minimum & 5.40 & 15.33 & 0.09 & 39.50 & 30.13 & 18.55 & 3.49 \\
\hline & & Maximum & 125.52 & 36.98 & 0.20 & 154.34 & 81.30 & 51.36 & 25.28 \\
\hline \multirow[t]{4}{*}{ Arable land } & 21 & Mean & 21.31 & 26.60 & .15 & 66.01 & 60.92 & 24.26 & 9.54 \\
\hline & & SD & 10.69 & 8.42 & .043 & 22.35 & 18.07 & 3.54 & 4.28 \\
\hline & & Minimum & .75 & 10.16 & .07 & 40.53 & 28.04 & 18.63 & 1.22 \\
\hline & & Maximum & 40.54 & 43.99 & .24 & 121.89 & 101.26 & 30.57 & 18.63 \\
\hline \multirow[t]{4}{*}{ Orchard } & 3 & Mean & 36.63 & 26.24 & .15 & 72.17 & 58.87 & 26.42 & 6.83 \\
\hline & & SD & 20.33 & 1.31 & .013 & 8.49 & 10.17 & 1.63 & 2.97 \\
\hline & & Minimum & 21.15 & 25.19 & .14 & 65.07 & 48.69 & 24.65 & 5.10 \\
\hline & & Maximum & 59.65 & 27.71 & .17 & 81.57 & 69.02 & 27.85 & 10.26 \\
\hline
\end{tabular}

a Background values of soil metals in Shandong Province (Wang and Wei, 1995).

be carried out in subsequent investigations to accurately evaluate the risk levels along the watershed and estuarine areas of southern Bohai Sea.

Sediment quality guidelines (SQGs) have been employed to identify 'contaminants of concern' in aquatic ecosystems, and meanwhile assess the health of sediment ecosystem. SQGs have also been used in numerous other applications (MacDonald et al., 2000; Pekey et al., 2004). Two levels from sediment quality guidelines were considered, Effects Range-Low (ERL) and the Effects Range-Median (ERM) (Long et al., 1998). These two assessment values, delineate three ranges of chemical concentrations that were either rarely ( $<E R L$ ), occasionally ( $\geqslant E R L$ and $<E R M$ ) or frequently ( $\geqslant E R M$ ) associated with adverse biological effects (Christophoridis et al., 2009; Luo et al., 2010).

Metal concentrations were compared with ERL and ERM values (Table 5). Results indicated that only a small percentage of sediments could be classified as possibly presenting an occasionally threat to organisms due to concentrations of $\mathrm{Pb}$ and $\mathrm{Cd}$. In addition, our data suggested that no sites exceeded the ERM guideline for $\mathrm{Pb}$ and $\mathrm{Cd}$. Eighty percent of sites were below the ERL guideline for $\mathrm{Cr}$, the concentrations of $\mathrm{Cr}$ in the rest of the sites would be classified as possibly presenting an occasional threat to organisms. The per- centages of samples with a Ni concentration exceeding the ERL and ERM values were $57.5 \%$ and $2.5 \%$, respectively. Out of all elements studied, Ni most often exceeded the ERL values. The percentages of the samples with $\mathrm{Cu}$ and $\mathrm{Zn}$ concentrations exceeding the ERL and ERM values were $25 \%$ and 5\%, $12.5 \%$ and 5\%, respectively. Among the investigated elements, $\mathrm{Cu}$ and $\mathrm{Zn}$ most often exceeded ERM values. The percentages of samples rarely, occasionally or frequently associated with adverse biological effects of As were 65\%, $32.5 \%$ and $2.5 \%$, respectively.

The above SQGs were established by comparing concentrations of each individual metal with their corresponding limit concentrations. However, naturally occurring metal pollution is usually in the form of combined pollution. So, the mean ERM quotient method was conducted to evaluate the possible biological effect of combined metal pollution (Carr et al., 1996). The calculation formula and related assessment criteria were listed in Appendix IV. As shown in Fig. 5, the mean ERM quotients of the surface sediments along the watershed and estuarine areas of southern Bohai Sea varied within the range of 0.03-1.66. Particularly, the mean ERM quotient of sampling site YT6 was 1.66, which means it has a $76 \%$ probability of being toxic. Meanwhile, the mean ERM quotient of sampling site YT5 was 0.56, which indicates it has a $49 \%$ 


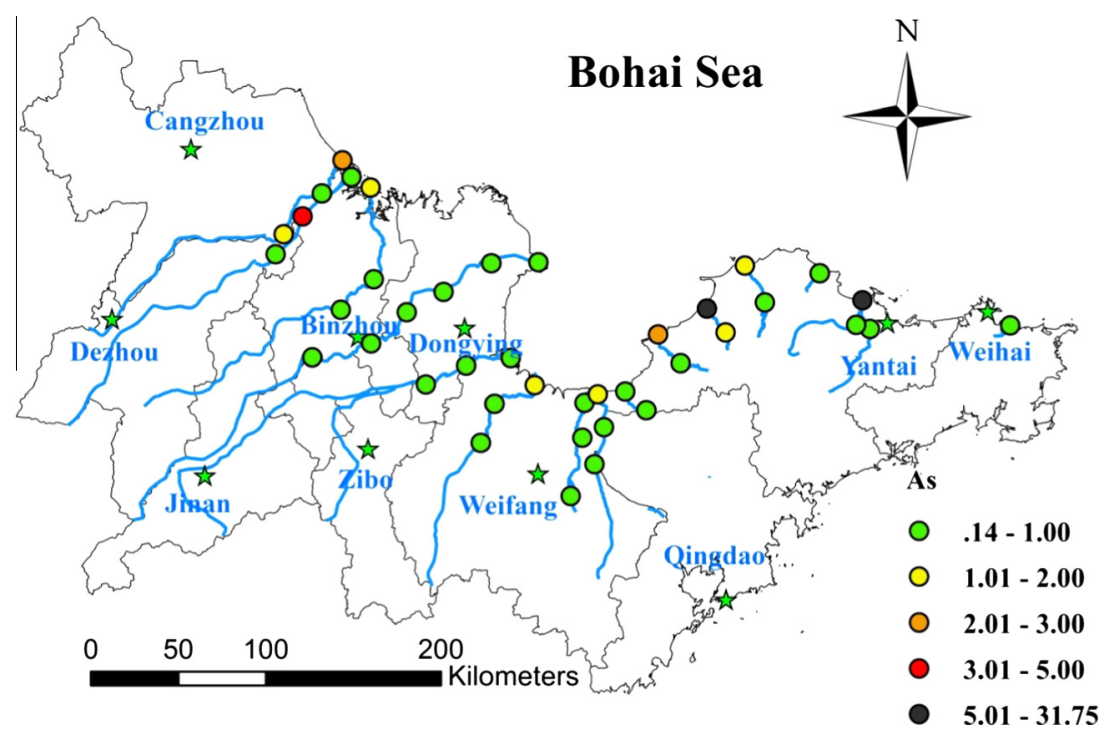

Fig. 4. Hazard Quotient of As in water along the watershed and estuarine areas of southern Bohai Sea.

Table 5

Classification of sediment samples based on the proposed SQGs.

\begin{tabular}{|c|c|c|c|c|c|}
\hline & \multicolumn{2}{|c|}{ SQGs $(\mathrm{mg} / \mathrm{kg})$} & \multicolumn{3}{|c|}{ Percentage of the samples exceeding SQGs (\% } \\
\hline & ERL & ERM & $<$ ERL & ERL-ERM & $>$ ERM \\
\hline $\mathrm{Cu}$ & 34 & 270 & 75 & 20 & 5 \\
\hline $\mathrm{Zn}$ & 150 & 410 & 87.5 & 7.5 & 5 \\
\hline $\mathrm{Cr}$ & 81 & 370 & 80 & 20 & 0 \\
\hline $\mathrm{Ni}$ & 20.9 & 51.6 & 42.5 & 55 & 2.5 \\
\hline $\mathrm{Pb}$ & 47 & 218 & 97.5 & 2.5 & 0 \\
\hline As & 8.2 & 70 & 65 & 32.5 & 2.5 \\
\hline $\mathrm{Cd}$ & 1.2 & 9.6 & 97.5 & 2.5 & 0 \\
\hline
\end{tabular}

probability of being toxic. Both of these two sampling sites were from the Jie River which might be polluted by gold mining and smelting. In addition, 29 sampling sites $(72.5 \%)$ had a probability of $21 \%$ of being toxic, while 9 sampling sites had a $9 \%$ probability of being toxic.
To assess the entire risk of metals and arsenic pollution in the soil along the watershed and estuarine areas of southern Bohai Sea, the quantitative approach which introduced a toxic-response factor for a given substance and thus can be used to evaluate the potential risk to an ecological system developed by Hakanson was used. The calculation formula and related assessment criteria were listed in Appendix V. As shown in Fig. 6, the RI of surface soils along the watershed and estuarine areas of southern Bohai Sea varied within the range of 28.87-139.28. The RI of sampling site CZ3 and BZ1 were 139.38 and 131, respectively, indicating considerable ecological risk. These two sampling sites were located at the watershed of Zhangweixin River and Majia River. It has been reported that the annual discharges of waste water from the Shangdong Lubei Enterprise Group General Company to the Zhangweixin River, Majia River and nearby estuary were $2.207 \times 10^{8}$ t (Liu et al., 2012). We also found that the high concentration of $\mathrm{Ni}, \mathrm{Cr}$ and As in surface sediment and large contents of $\mathrm{Cr}$ and As in water in this area. Contamination with metals therefore deserves more attention from the local government in this area. In addition, a

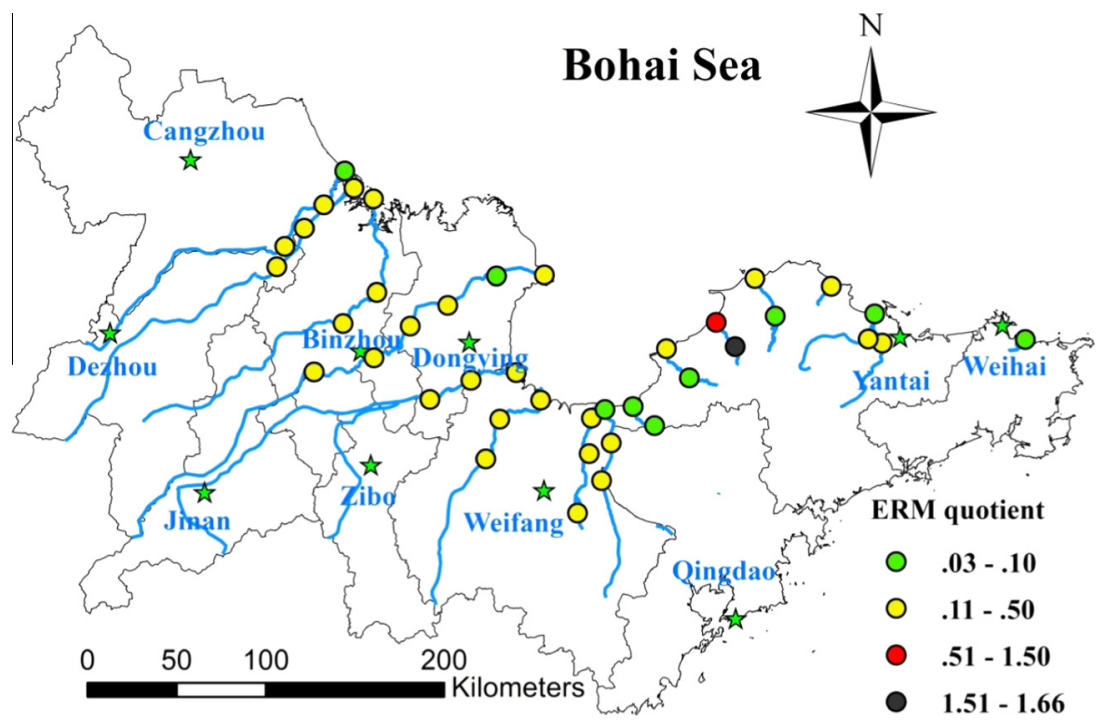

Fig. 5. ERM quotient of metals and arsenic in sediment along the watershed and estuarine areas of southern Bohai Sea. 


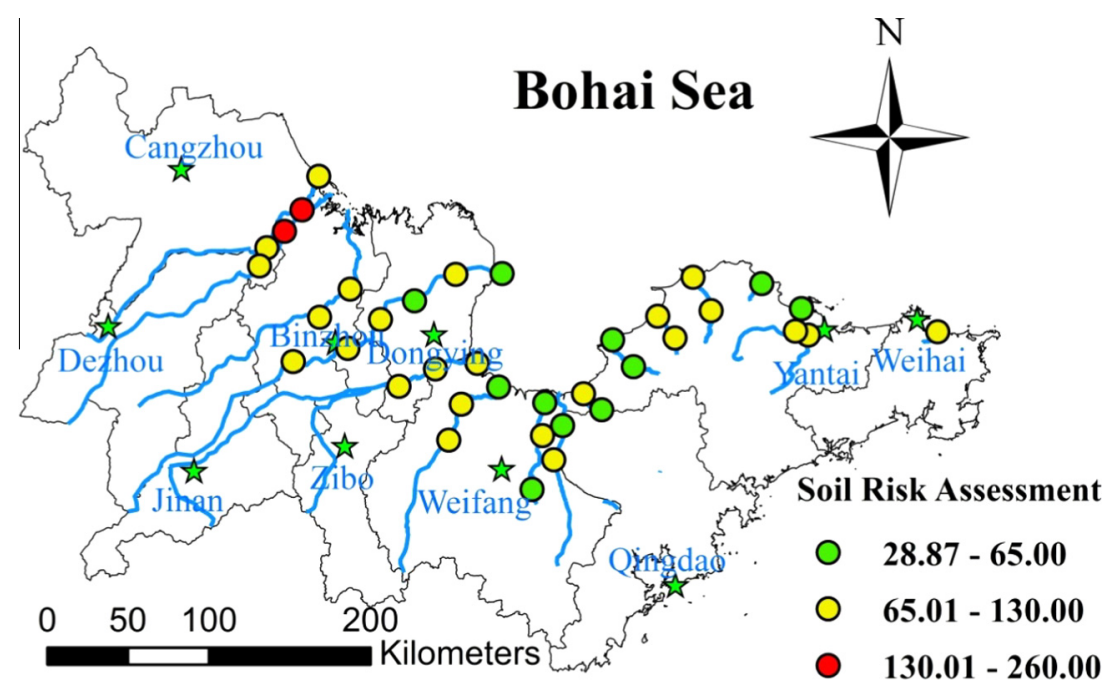

Fig. 6. Ecological risk of metals and arsenic in soil along the watershed and estuarine areas of southern Bohai Sea.

total of 24 sampling sites (64.86\%) had moderate ecological risk, while 11 sampling sites had low ecological risk.

The present study is a part of an ongoing project to determine the concentration, distribution, sources and environmental fate of metals in the Bohai Sea ecosystem. In the present study, the metal concentrations in water, sediments and soils collected along the watershed and estuarine areas of southern Bohai Sea were determined. The results presented in this paper may help develop a better understanding of the geographic distribution and extent of metals and arsenic pollution along the watershed and estuarine areas of southern Bohai Sea. We did not collect or study biological samples as part of this study, however. In future work we will collect and investigate various biological samples such as fish, birds and aquatic plants. The complete set of data will be eventually used for the comprehensive assessment of the risk levels of metal contaminations along the watershed and estuarine areas of southern Bohai Sea.

\section{Acknowledgments}

This study was supported by the National Natural Science Foundation of China under Grant Nos. 41071355 and 41171394, the International S\&T Cooperation Project (2012DFA91150), the Key Project of the Chinese Academy of Sciences under Grant No. KZZD-EW-TZ-12, and the Environmental Protection Welfare Program under Grant No. 201009032. We thank the editors and reviewers for their valuable comments and suggestions.

\section{Appendix A. Supplementary material}

Supplementary data associated with this article can be found, in the online version, at http://dx.doi.org/10.1016/j.marpolbul.2013. 06.010.

\section{References}

Andres, N.F., Francisco, M.S., 2008. Effects of sewage sludge application on heavy metal leaching from mine tailings impoundments. Bioresour. Technol. 99, 7521-7530.

Babic, S., Kastelan, M.M., Petrovic, M., 1998. Determination of agrochemical combinations in spiked soil samples. Water. Sci. Technol. 37, 243-250.

Besnard, E., Chenu, C., Robert, M., 2001. Influence of organic amendments on copper distribution among particle-size and density fractions in Champagne vineyard soils. Environ. Pollut. 112, 329-337.
Carr, R.S., Long, E.R., Windom, H.L., Chapman, D.C., Thursby, G., Sloane, G.M., Wolfe D.A., 1996. Sediment quality assessment studies of Tampa Bay, Florida. Environ. Toxicol. Chem. 15, 1218-1231.

Cheng, S.P., 2003. Heavy metal pollution in China: origin, pattern and control Environ. Sci. Pollut. Res. 10, 192-198.

Christophoridis, C., Dedepsidis, D., Fytianos, K., 2009. Occurrence and distribution of selected heavy metals in the surface sediments of Thermaikos Gulf, N. Greece. assessment using pollution indicators. J. Hazard. Mater. 168, 1082-1091.

CSBTS (China State Bureau of Quality and Technical Supervision). 2008. The People's Republic of China National Standards GB 22105-2008-Determination of Total $\mathrm{Hg}$, As in soil by Atomic Fluorescence Spectrometry (in Chinese).

Davis, A., Atkins, D., 2001. Metal distribution in Clark Fork River sediments. Environ. Sci. Technol. 35, 3501-3506.

de Vries, W., Reinds, G.J., Vel, E., 2003. Intensive monitoring of forest ecosystems in Europe 2: atmospheric deposition and its impacts on soil solution chemistry. Forest. Ecol. Manage. 174, 97-115.

Deluisa, A., Giandon, P., Aichner, M., Bortolami, P., Bruna, L., Lupetti, A., Nardelli, F., Stringari, G., 1996. Copper pollution in Italian vineyard soils. Commun. Soil Sci. Plan. 27, 1537-1548.

Edinger, E.N., Azmy, K., Diegor, W., Siregar, P.R., 2008. Heavy metal contamination from gold mining recorded in Porites lobata skeletons, Buyat-Ratototok district North Sulawesi, Indonesia. Mar. Pollut. Bull. 56, 1553-1569.

Feng, H.A., Jiang, H.Y., Gao, W.S., Weinstein, M.P., Zhang, Q.F., Zhang, W.G., Yu L.Z., Yuan, D.K., Tao, J.H., 2011. Metal contamination in sediments of the western Bohai Bay and adjacent estuaries. China. J. Environ. Manage. 92, 1185-1197.

Fukushima, K., Saino, T., Kodama, Y., 1992. Trace-metal contamination in Tokyo Bay, Japan. Sci. Total Environ. 125, 373-389.

Gao, X.L., Chen, C.T.A., 2012. Heavy metal pollution status in surface sediments of the coastal Bohai Bay. Water. Res. 46, 1901-1911.

Gaw, S.K., Palmer, G., Kim, N.D., Wilkins, A.L., 2003. Preliminary evidence that copper inhibits the degradation of DDT to DDE in pip and stonefruit orchard soils in the Auckland region, New Zealand. Environ. Pollut. 122, 1-5.

Hamer, K., Karius, V., 2002. Brick production with dredged harbour sediments. An industrial-scale experiment. Waste. Manage. 22, 521-530.

Holland, P., Solomona, S., 1999. Copper status of orchards. The Orchardist 72, 44-45

Hu, N.J., Shi, X.F., Liu, J.H., Huang, P., Yang, G., Liu, Y.G., 2009. Distributions and impacts of heavy metals in the surface sediments of the Laizhou Bay. Adv. Marine Sci. 29, 36-72 (in Chinese)

Hu, W.Y., Wang, T.Y., Khim, J.S., Luo, W., Jiao, W.T., Lu, Y.L., Naile, J.E., Chen, C.L., Zhang, X.A., Giesy, J.P., 2010. HCH and DDT in Sediments from Marine and Adjacent Riverine Areas of North Bohai Sea, China. Arch. Environ. Contam. Toxicol. 59, 71-79.

Huang, H.R., Pang, X.Z., 1992. Heavy metals in sediments of tidal zone from southwest Bohai Sea. Mar. Sci. 5, 44-47 (in Chinese).

Hyun, S., Lee, C.H., Lee, T., Choi, J.W., 2007. Anthropogenic contributions to heavy metal distributions in the surface sediments of Masan Bay, Korea. Mar. Pollut. Bull. 54, 1059-1068.

Ip, C.C.M., Li, X.D., Zhang, G., Wai, O.W.H., Li, Y.S., 2007. Trace metal distribution in sediments of the Pearl River Estuary and the surrounding coastal area, South China. Environ. Pollut. 147, 311-323.

Karageorgis, A.P., Sioulas, A.I., Anagnostou, C.L., 2002. Use of surface sediments in Pagassitikos Gulf, Greece, to detect anthropogenic influence. Geo-Mar. Lett. 21, 200-211.

Karim, Z., 2011. Risk assessment of dissolved trace metals in drinking water of Karachi, Pakistan. Environ. Contam. Toxicol. B 86, 676-678.

Klavins, M., Briede, A., Rodinov, V., Kokorite, I., Parele, E., Klavina, I., 2000. Heavy metals in rivers of Latvia. Sci. Total Environ. 262, 175-183. 
Kim, D.S., An, K.G., Kim, K.H., 2003. Heavy metal pollution in the soils of various land use types based on physicochemical characteristics. J Environ. Sci. Heal A. 38 839-853.

Krishna, A.K., Satyanarayanan, M., Govil, P.K., 2009. Assessment of heavy metal pollution in water using multivariate statistical techniques in an industria area: a case study from Patancheru, Medak District, Andhra Pradesh, India. J. Hazard. Mater. 167, 366-373.

Li, S.Y., Zhang, Q.F., 2010a. Risk assessment and seasonal variations of dissolved trace elements and heavy metals in the Upper Han River, China. J. Hazard. Mater. 181, 1051-1058.

Li, S.Y., Zhang, Q.F., 2010b. Spatial characterization of dissolved trace elements and heavy metals in the upper Han River (China) using multivariate statistical techniques. J. Hazard. Mater. 176, 579-588.

Liu, Y.F., Wu, S.Y., Sun, S.X., Sun, Y.G., 2009. Comparison between sediment contamination in intertidal zone of Jiaozhou Bay and Laizhou Bay. Coast. Eng. 28, 61-68 (in Chinese).

Liu, Z.J., Li, P.Y., Zhang, X.L., Li, P., Zhu, L.H., 2012. Regional distribution and ecological risk evaluation of heavy metals in surface sediments from coasta wetlands of the Yellow River Delta. Environ. Sci. 33, 1182-1188 (in Chinese).

Long, E.R., Field, L.J., MacDonald, D.D., 1998. Predicting toxicity in marine sediments with numerical sediment quality guidelines. Environ. Toxicol. Chem. 17, 714727.

Luo, W., Lu, Y.L., Giesy, J.P., Wang, T.Y., Shi, Y.J., Wang, G., Xing, Y., 2007a. Effects of land use on concentrations of metals in surface soils and ecological risk around Guanting Reservoir, China. Environ. Geochem. Health 29, 459-471.

Luo, W., Lu, Y.L., Wang, T.Y., Hu, W.Y., Jiao, W.T., Naile, J.E., Khim, J.S., Giesy, J.P., 2010. Ecological risk assessment of arsenic and metals in sediments of coastal areas of northern Bohai and Yellow Seas, China. Ambio 39, $367-$ 375.

Luo, W., Wang, T.Y., Lu, Y.L., Giesy, J.P., Shi, Y.J., Zheng, Y.M., Xing, Y., Wu, G.H. 2007b. Landscape ecology of the Guanting Reservoir, Beijing, China: multivariate and geostatistical analyses of metals in soils. Environ. Pollut. $146,567-576$.

MacDonald, D.D., Ingersoll, C.G., Berger, T.A., 2000. Development and evaluation of consensus-based sediment quality guidelines for freshwater ecosystems. Arch. Environ. Contam. Toxicol. 39, 20-31.

Mapanda, F., Mangwayana, E.N., Nyamangara, J., Giller, K.E., 2005. The effect of longterm irrigation using wastewater on heavy metal contents of soils under vegetables in Harare, Zimbabwe. Agr. Ecosyst. Environ. 107, 151-165.

Melo, G., Fletcher, W.K., 1999. Dispersion of gold and associated elements in stream sediments under semi-arid conditions, northeast Brazil. J. Geochem. Explor. 67, 235-243.

Meng, W., Qin, Y.W., Zheng, B.H., Zhang, L., 2008. Heavy metal pollution in Tianjin Bohai Bay, China. J. Environ. Sci.-China. 20, 814-819.

Merry, R.H., Tiller, K.G., Alston, A.M., 1983. Accumulation of copper, lead and arsenic in some Australian orchard soils. Aust. J. Soil Res. 21, 549-561.

Ministry of Health of China, 2007. Standards for Drinking Water, Quality, GB57492006.

Nan, Z.R., Li, J.J., Zhang, J.M., Cheng, G.D., 2002. Cadmium and zinc interactions and their transfer in soil-crop system under actual field conditions. Sci. Total Environ. 285, 187-195.

NEB (National Environmental Bureau), 1998. Water and Waste Analysis, third ed. Chinese Environmental Science Publish House, Beijing (in Chinese).

Nicholson, F.A., Smith, S.R., Alloway, B.J., Carlton-Smith, C., Chambers, B.J., 2003. An inventory of heavy metals inputs to agricultural soils in England and Wales. Sci. Total Environ. 311, 205-219.

Pan, K., Wang, W.X., 2012. Trace metal contamination in estuarine and coasta environments in China. Sci. Total Environ. 421, 3-16.
Pekey, H., 2006. The distribution and sources of heavy metals in Izmit Bay surface sediments affected by a polluted stream. Mar. Pollut. Bull. 52, 1197-1208.

Pekey, H., Karakas, D., Ayberk, S., Tolun, L., Bakoglu, M., 2004. Ecological risk assessment using trace elements from surface sediments of Izmit Bay (Northeastern Marmara Sea) Turkey. Mar. Pollut. Bull. 48, 946-953.

Ramirez-Fuentes, E., Lucho-Constantino, C., Escamilla-Silva, E., Dendooven, L., 2002. Characteristics, and carbon and nitrogen dynamics in soil irrigated with wastewater for different lengths of time. Bioresource. Technol. 85, 179-187.

USEPA, 2006. Resources for Information on Risk-Based Concentration Table.

Sun, X., 2009. In: Management and Policy along the Watershed of Xiaoqing River in Shandong Province, Shandong University. Shandong University, p. 75.

Tang, A.K., 2011. The influence factors and behavior characteristics of heavy metals from river to sea in Yellow River. Ocean University of China. Master Thesis (in Chinese).

Tarras-Wahlberg, N.H., Flachier, A., Lane, S.N., Sangfors, O., 2001. Environmental impacts and metal exposure of aquatic ecosystems in rivers contaminated by small scale gold mining: the Puyango River basin, southern Ecuador. Sci. Total Environ. 278, 239-261.

van Straaten, P., 2000. Mercury contamination associated with small-scale gold mining in Tanzania and Zimbabwe. Sci. Total Environ. 259, 105-113.

Wang, C.Y., Wang, X.L., 2007. Spatial distribution of dissolved Pb, Hg, Cd, Cu and as in the Bohai sea. J. Environ. Sci-China. 19, 1061-1066.

Wang, L., Wang, Y.P., Xu, C.X., An, Z.Y., Wang, S.M., 2011a. Analysis and evaluation of the source of heavy metals in water of the River Changjiang. Environ. Monit. Assess. 173, 301-313.

Wang, T.Y., Lu, Y.L., Chen, C.L., Naile, J.E., Khim, J.S., Park, J., Luo, W., Jiao, W.T., Hu, W.Y., Giesy, J.P., 2011b. Perfluorinated compounds in estuarine and coastal areas of north Bohai Sea, China. Mar. Pollut. Bull. 62, 1905-1914.

Wang, Y., Wei, F., 1995. Soil Environmental Element Chemistry. China Environmental Science Press.

Wei, S., Lau, R.K.F., Fung, C.N., Zheng, G.J., Lam, J.C.W., Connell, D.W., Fang, Z., Richardson, B.J., Lam, P.K.S., 2006. Trace organic contamination in biota collected from the Pearl River Estuary, China: a preliminary risk assessment. Mar. Pollut. Bull. 52, 1682-1694.

World Health Organization, 2006. Guidelines for drinking water quality, third ed. Geneva.

Wu, B., Zhao, D.Y., Jia, H.Y., Zhang, Y., Zhang, X.X., Cheng, S.P., 2009. Preliminary risk assessment of trace metal pollution in surface water from Yangtze River in Nanjing section, China. Environ. Contam. Toxicol. B 82, 405-409.

Xu, L., Luo, W., Lu, Y.L., Wang, T.Y., Chen, C.L., Giesy, J.P., Zhang, Y., Li, J., Gosens, J., 2011. Status and fuzzy comprehensive assessment of metals and arsenic contamination in farmland soils along the Yanghe River, China. Chem. Ecol. 27, 415-426.

Wu, X.Y., Liu, R.H., Qin, J., Sun, P.Y., Gao, Z.H., Jia, Y.G., 2007. The variance character of heavy metals contents in sediments in Yellow River estuary. Trans. Oceanol. Limnol. 13, 69-74 (in Chinese).

Zhan, S.F., Peng, S.T. Liu, C.G., Chang, Q., Xu, J., 2010. Spatial and temporal variations of heavy metals in surface sediments in Bohai Bay, North China. Environ. Contam. Toxicol. B 84, 482-487.

Zhang, W.G., Feng, H., Chang, J.N., Qu, J.G., Xie, H.X., Yu, L.Z., 2009. Heavy metal contamination in surface sediments of Yangtze River intertidal zone: an assessment from different indexes. Environ. Pollut. 157, 1533-1543.

Zhang, X.X., 2010. The Variance Characteristics of Heavy Metal in the Lower Reaches of the Yellow River and Sediment of Estuarine Wetland. Ocean University of China. Master Thesis. (in Chinese).

Zhang, Y.L., Dai, J.L., Wang, R.Q., Zhang, J., 2008. Effects of long-term sewage irrigation on agricultural soil microbial structural and functional characterizations in Shandong, China. Eur. J. Soil Biol. 44, 84-91. 